\title{
MENINGKATKAN KEMAMPUAN BERBICARA PADA SISWA KELAS IV SD NEGERI 38 KOTA TERNATE MELALUI MODEL PEMBELAJARAN ROLE PLAY
}

\author{
Kodrat Hi. Karim, Suhardi Abdullah \\ Dosen Program Studi Pendidikan Guru Sekolah Dasar FKIP Unkhair \\ Email: kodrathkarim@gmail.com
}

\begin{abstract}
Abstrak
Penelitian ini dilakukan untuk mengetahui bagaimana penggunaan role play dalam meningkatkan kemmapuan berbicara sisiwa kelas IV SD Negeri 3 Guruapin, serta untuk mengetahui sejauhmana penggunaan role play dalam meningkatkan kemampuan berbicara siswa kelas IV SD Negeri 38 Kota Ternate. Penelitian ini dilaksanakan di kelas IV dengan melibatkan 37 siswa dan guru kelas sebagai sumber data. Metode penelitian yang digunakan adalah penelitian tindakan kelas dengan 2 siklus pembelajaran. Setiap siklus terdiri dari 4 tahapan, yakni perencanaan, pelaksanaan, observasi, dan refleksi. Penelitian dilaksanakan dalam dua siklus. Setiap sikluas dilaksanakan dua kali tatap muka. Dari hasil penelitian tindakan kelas tentang penggunaan role play dalam meningkatkan kemampuan berbicara siswa kelas IV SD Negeri 38 Kota Ternate dapat ditemukan bahwa siklus I terdapat 18 siswa atau $48.64 \%$ siswa dinyatakan tuntas belajar, sementara 19 siswa atau $51.35 \%$ siswa dinyatakan belum tuntas. Kemudian meningkat pada tindakan siklus II yaitu sebanyak 30 siswa atau $81.08 \%$ dinyatakan mencapai ketuntasan belajar, dan terdapat 7 siswa atau $18.91 \%$ siswa dinyatakan belum tuntas. Adapun peningkatan dari tindakan siklus I ke siklus II adalah sebesar $31.44 \%$.
\end{abstract}

Kata Kunci: Bahasa Indonesia, Berbicara, Role Play

\section{PENDAHULUAN}

Standar kompetensi mata pelajaran bahasa Indonesia ditegaskan bahwa pembelajaran bahasa Indonesia adalah belajar berkomunikasi dan belajar sastra guna menghargai manusia dan nilia-nilai kemanusiaan (Depdiknas, 2004: 2). Pembelajaran bahasa Indonesia diarahkan untuk meningkatkan kemampuan siswa untuk berkomunikasi dalam bahasa Indonesia, baik lisan maupun tulis serta menimbulkan pengharagaan terhadap isi cipta manusia. Oleh karena itu, ruang lingkup pembelajaran bahasa Indonesia di SD terdiri dari aspek aspek mendengarkan/menyimak, berbicara, menulis dan membaca.

Dalam kegiatan belajar mengajar digunakan bahasa Indonesia sebagai bahasa pengantar, terutama mata pelajaran Bahasa dan Sastra Indonesia. Setidaknya hal ini dapat dijadikan contoh bagi para siswa dalam kegiatan berbicara dalam suasana 
formal. Berdasarkan hasil observasi terhadap siswa kelas IV SD Negeri 38 Kota ternate, diketahui bahwa siswa masih mengalami kesulitan untuk menyampaikan ide, pikiran, gagasan, perasaan dan lain sebagainya dalam situasi formal dengan baik dan benar. Pola interaksi siswa kelas IV SD Negeri 38 Kota Ternate, adalah: (1) mereka lebih banyak menggunakan bahasa Melayu Ternate untuk berkomunikasi dengan teman sejawat maupun guru, (2) dalam proses belajar mengajar, siswa bertanya, mengajukan pertanyaan atau pendapat dan sebagainya, guru kurang memperhatikan pemakaian ragam bahasa siswa, (3) jika diharuskan untuk menggunakan bahasa Indonesia baku, siswa mengalami kesulitan untuk berkomunikasi secara lancar. Hal ini disebabkan masih rendahnya penguasaan kosa kata bahasa Indonesia oleh siswa terteliti.

Dengan kondisi tersebut, tentunya suasana belajar di kelas bahasa menjadi kurang kondusif, begitu pula dengan motivasi belajar siswanya yang rendah. Sekalipun materi-materi yang diajarkan tergolong sangat sederhana namun tidak membuat siswa dapat mudah menerima ataupun tertarik mempelajarinya. Di samping itu kemampuan berbahasa yang digunakan ssiwa juga masih jauh dari yang diharapkan.

Dari permasalahan tersebut, peneliti ingin memberi variasi lain untuk menumbuhkan ketertarikan sekaligus mengembangkan kemampuan berbahsa Indonesia siswa. Oleh karena itu, salah satu strategi yang gunakan adalah belajar sambil bermain, yang dikemas dalam sebuah permainan peran atau yang dikenal dengan role play. Hal ini dimaksudkan agar siswa merasa senang dengan pembelajaran bahasa Indonesia. Dengan role play, siswa diharapkan dapat menggunakan pilihan kosakata, kalimat, ujaran, pelafalan maupun unsur bahasa lainnya dengan baik dan benar.

Ladousse (1987: 81) menegaskan role-play menambah variasi, perubahan perilaku dan kesempatan menggunakan kalimat dengan benar serta banyak kesenangan. Pendapat ini didukung oleh Arsjad (1998: 23) yang menyatakan bahwa banyak ahli terampil menuangkan gagasannya dalam bentuk tulisan, namun mereka sering kurang terampil menyajikannya secara lisan. Apalagi berbicara secara formal tidaklah semudah yang dibayangkan orang. Walaupun secara alamiah setiap orang mampu berbicara, namun berbicara secara formal atau dalam situasi resmi sering menimbulkan kegugupan sehingga gagasan yang dikemukakan menjadi tidak teratur. Bahkan yang lebih parah lagi ada orang yang tidak berani berbicara sama sekali. Anggapan bahwa setiap orang dengan sendirinya dapat berbicara, telah menyebabkan pembinaan kemampuan berbicara ini sering diabaikan. 
Dengan demikian, tujuan dari penelitian ini adalah setelah kegiatan pembelajaran Indonesia dengan menggunakan Role Play siswa diharapkan mengetahui bagaimana penggunaan role play dapat meningkatkan kemampuan berbicara bahasa Indonesia Kelas IV SD Negeri 38 Kota Ternate, serta untuk mengetahui sejauhmana penggunaan role play dalam meningkatkan kualitas pembelajaran bahasa Indonesia IV SD Negeri 38 Kota Ternate.

\section{Konsep Berbicara}

Pada hakikatnya keterampilan berbicara adalah keterampilan mengucapkan bunyi-bunyi artikulasi atau kata-kata untuk mengekspresikan, menyatakan serta menyampaikan pikiran, gagasan, dan perasaan (Tarigan, 1990: 15). Keterampilan berbicara sangat penting dimiliki seseorang agar tidak terjadi kesalahpahaman antara penutur dan mitra tutur dalam berkomunikasi. Bentuk komunikasi lisan ini paling banyak digunakan orang dalam kehidupan sehari-hari, karena bentuk komunikasi verbal dianggap paling sempurna, efisien dan efektif (Yuniawan, 2002: $1)$.

Ujaran (speech) merupakan suatu bagian yang integral dari keseluruhan personalitas atau kepribadian, mencerminkan lingkungan sang pembicara, kontakkontak sosial, dan pendidikannya. Aspek-aspek lain seperti cara berpakaian atau mendandani pengantin, adalah bersifat eksternal, tetapi ujaran sudah bersifat inheren, pembawaan (Tarigan,1996: 15)

Berbicara adalah kemampuan mengucapkan bunyi-bunyi artikulasi atau kata-kata untuk mengekspresikan, menyatakan serta menyampaikan pikiran, gagasan dan perasaan. Sebagai perluasan dari batasan ini dapat kita katakan bahwa berbicara merupakan suatu sistem tanda-tanda yang dapat didengar (audible) dan yang kelihatan (visible) yang memanfaatkan sejumlah otot dan jaringan otot tubuh manusia demi maksud dan tujuan gagasan-gagasan atau ide-ide yang dikombinasikan. Lebih jauh lagi, berbicara merupakan suatu bentuk perilaku manusia memanfaatkan faktor-faktor fisik, psikologis,neurologis, semantik, dan linguistik sedemikian ekstensif, secara luas sehinga dapat dianggap sebagai alat manusia yang paling penting bagi kontrol sosial (Tarigan,1996: 15).

Dengan demikian berbicara itu lebih daripada hanya sekedar pengucapan bunyi atau kata-kata. Berbicara adalah suatu alat untuk mengkomunikasikan gagasan-gagasan yang disusun serta dikembangkan sesuai dengan kebutuhankebutuhan sang pendengar atau penyimak. Berbicara merupakan instrument yang mengungkapkan kepada penyimak hampir-hampir secara langsung apakah sang pembicara memahamai atau tidak, baik bahan pembicaraanya maupun para 
penyimaknya: apakah dia bersikap tenang, serta dapat menyesuaikan diri atau tidak, pada saat dia mengkomunikasikan gagasan-gagasannya; dan apakah dia waspada serta antusias atau tidak (Mulgrave, 1954: 3-4).

\section{Faktor-faktor Penunjang Efektifitas Berbicara}

Ada beberapa faktor yang perlu diperhatikan seseorang untuk dapat menjadi pembicara yang baik. Faktor-faktor tersebut adalah faktor kebahasaan dan faktor nonkebahasaan (Arsjad dan Mukti, 1988: 17).

a) Faktor Kebahasaan meliputi:

1. Ketepatan Ucapan; Seorang pembicara harus membiasakan diri mengucapkan bunyi-bunyi bahasa secara tepat. Pengucapan bunyi-bunyi bahasa yang kurang tepat dapat mengalihkan perhatian pendengar. Hal ini akan mengganggu keefektivan berbicara. Pengucapan bunyi-bunyi bahasa yang kurang tepat atau cacat akan menimbulkan kebosanan, kurang menyenangkan, kurang menarik, atau setidaknya dapat mengalihkan perhatian pendengar.

2. Penempatan Tekanan, Nada, Sendi, dan Durasi yang Sesuai

Kesesuaian tekanan, nada, sendi, dan durasi merupakan daya tarik tersendiri dalam berbicara, bahkan kadang-kadang merupakan faktor penentu. Walaupun masalah yang dibicarakan kurang menarik, dengan penempatan tekanan, nada, sendi, dan durasi yang sesuai akan menyebabkan masalahnya menjadi menarik.

3. Pilihan Kata (Diksi)

Pilihan kata hendaknya tepat, jelas dan bervariasi. Jelas maksudnya mudah dimengerti oleh pendengar yang menjadi sasaran. Pendengar akan lebih mudah memahami isi pembicaraan kita kalau kata-kata yang digunakan sudah dikenal pendengar.

4. Ketepatan Sasaran Pembicaraan

Hal ini menyangkut pemakaian kalimat. Pembicara yang menggunakan kalimat efektif akan memudahkan pendengar menangkap pembicaraannya. Seorang pembicara harus mampu menyusun kalimat efektif, kalimat yang mengenai sasaran, sehingga mampu menimbulkan pengaruh, meninggalkan kesan atau menimbulkan akibat.

b) Faktor Non-kebahasaan

1. Sikap yang Wajar

Penguasaan materi yang baik setidaknya akan menghilangkan kegugupan. 
Namun, sikap ini memerlukan latihan. Kalau sudah terbiasa, lamakelamaan rasa gugup akan hilang dan akan timbul sikap tenang dan wajar.

2. Pandangan Harus Diarahkan Kepada Lawan Bicara

Pandangan pembicara hendaknya diarahkan kepada semua pendengar. Pandangan yang hanya tertuju pada satu arah akan menyebabkan pendengar merasa kurang diperhatikan. Banyak pembicara ketika berbicara tidak memperhatikan pendengar, tetapi melihat ke atas, ke samping atau menunduk. Akibatnya, perhatian pendengar berkurang. Hendaknya diusahakan supaya pendengar merasa terlibat dan diperhatikan.

3. Kesediaan Menghargai Pendapat Orang Lain

Dalam menyampaikan isi pembicaraan, seorang pembicara hendaknya memiliki sikap terbuka, dalam arti dapat menerima pendapat pihak lain, bersedia menerima kritik, bersedia mengubah pendapatnya kalau ternyata memang keliru.

4. Gerak-gerik dan Mimik yang Tepat

Gerak-gerik dan mimik yang tepat dapat pula menunjang keefektivan berbicara. Hal-hal penting selain mendapatkan tekanan, biasanya juga dibantu degan gerak tangan atau mimik.

\section{Kelancaran}

Seorang pembicara yang lancar berbicara akan memudahkan pendengar menangkap isi pembicaraannya. Seringkali pembicara berbicara terputusputus, bahkan antara bagian-bagian yang terputus itu diselipkan bunyibunyi tertentu yang mengganggu penangkapan pendengar.

\section{Metode Role Play}

1. Penegetian Role play

Role play berasal dari kata 'role' yang artinya ambil bagian dalam sebuah kegiatan khusus dan 'play' yang artinya peranan itu diambil/dipakai dalam sebuah lingkungan dimana siswa dapat mengembangkan sepenuhnya daya cipta dan bermain. Sekelompok siswa bermain peran di dalam kelas dengan baik sama halnya dengan sekolompok anak yang sedang bermain sekolah-sekolahan, perawat dan dokter, atau peran lainnya.

Pernyataan yang hampir sama diungkapkan oleh Budden (2006: 74), role play adalah kegiatan berbicara dimana pemain dapat berperan menjadi orang lain atau dapat berperan menjadi dirinya sendiri tetapi berimajinasi dalam berbagai situasi. Orang yang berimajinasi adalah bahwa siswa dapat berperan dalam waktu 
tertentu sebagai jutawan, bintang film dan lain lain. Siswa juga dapat berpendapat seperti orang lain yang sedang mereka perankan. Sementara situasi imajinatif adalah bahwa bahasa yang digunakan menurut skenario situasi yang diperankan, misalnya di restoran, check in di bandara dan lain-lain. Dengan demikian, role play adalah suatu kegiatan berbicara dimana pemain dapat berperan sebagai orang lain maupun dirinya sendiri dalam berbagai situasi imajinatif yang mampu mengembangkan kemampuan daya cipta dan bermain sepenuhnya.

2. Hal - hal yang perlu diperhatikan dalam Role Play

a. Siap untuk berhasil

Role play di tingkat dasar. Mencoba memikirkan bahasa yang akan siswa gunakan. Siswa mungkin perlu ekstra dukungan untuk memiliki bahasa tersebut. Ketika mereka sedang bermain peran, siswa merasa telah dilengkapi dengan bahasa yang memadai. Untuk tingkat lebih tinggi, siswa tidak perlu banyak dukungan tetapi mereka perlu waktu masuk dalam peranan itu.

b. Peranan Guru

Beberapa kemungkinan peranan guru, yakni (1) Fasilitator, siswa mungkin membutuhkan kosakata baru dari guru, (2) Penonton: guru mengamati, memberi komentar dan nasehat pada akhirnya, (3) Partisipan: kadang-kadang ikut ambil peranan pada permainan tersebut

c. Bawalah situasi kegiatan menjadi hidup. Bermain perang dengan mengambil cerita dan juga properti yang nyata, misalnya berperan sebagai pemilik pizza dengan pelanggannya. Hal ini akan membuat pembelajaran lebih menyenangkan dan mudah diingat.

d. Tetap nyata dan relevan. Cobalah menjaga peranan siswa untuk bermain senyata mungkin. Walaupun itu sulit siswa diajak untuk membayangkan kegiatan tersebut terjadi di jantung kota di Inggris.

e. Gunakan imajinasimu dan bersenanglah.

Bermain peran yang paling sukses yang saya lakukan tahun lalu bersama dengan sekelompok remaja. Kelas dibagi dengan kelompok berpasangan dengan memerankan skater boy yang akhirnya mempertemukan mantan teman wanitanya diakhir konser. Hasilnya sangat lucu dan saya terkejut ketika mereka semua ikut ambil peranan. Akhirnya, Role play bisa menjadi kegiatan yang menyenangkan. Anda mungkin terkejut dengan hasil akhirnya. 


\section{METODE PENELITIAN}

Penelitian ini menggunakan Penelitian Tindakan Kelas (PTK) atau disebut Classroom Action Research (CAR). Penelitian Tindakan Kelas ini dilakukan melalui 4 tahap, yakni: Perencanaan, Pelaksanaan, Pengamatan, dan Refleksi. Penelitian ini dilaksanan di kelas IV SD Negeri 38 Kota Ternate tahun pelajaran 2018-2019 dengan jumlah siswa sebanyak 37 siswa. Jenis data yang dihimpun adalah data hasil belajar berbicara selama tindakan pembelajaran berlangsung. Pengumpulan data penelitian dilakukan melalui teknik tes, observasi, dan dokumentasi. Analisis data yang digunakan dalam penelitian ini menggunakan statistik diskripsi. Adapun diskripsi yang dipakai untuk mengetahui kemampuan berbicara bahasa Indonesia dengan menggunakan role play adalah sebagai berikut: 1) Pemahaman, 2) Kelancaran, 3) Pelafalan, 4) Isi cerita, 5) Sikap, dan 6) Struktur.

\section{PEMBAHASAN}

\section{A. Hasil}

\section{Pembelajaran Siklus I}

\section{Penyusunan Rencana Tindakan}

Pada tahap ini telah dilaksanakan penyusunan rencana tindakan yang meliputi, 1) rencana pembelajaran, 2) jadwal kegiatan siklus 1,3) rubrik penilaian role play, 4) lembar pengamatan untuk guru, dan 5) lembar angket siswa.

\section{Pelaksanaan Tindakan}

Pembelajaran diawali dengan penataan ruang kelas yang sesuai untuk kegiatan role play oleh masing-masing kelompok. Tempat duduk disetting dalam kelompok. Waktu yang dibutuhkan untuk pelaksanaan tindakan ini adalah 4 x 35 menit atau dua kali pertemuan, setiap pertemuan membutuhkan waktu 2 x 35 menit. Pertemuan pertama digunakan untuk penyampaian materi dan pembagian kelompok peran. Pertemuan kedua untuk pelaksanaan role play/unjuk kerja masing-masing kelompok. Pembelajaran diawali dengan tanya jawab guru dan siswa tentang kehidupan di sekolah. Setelah itu peneliti menjelaskan kegiatan yang akan diikuti selama pembelajaran. Tatap muka pertama dilaksanakan tanggal 19 September 2018 dengan kegiatan pemberian materi dan pembagian kelompok. Ssiwa dibagi dalam 5 kelompok yang beranggotakan masing-masing 7 - 8 siswa. 
Tatap muka kedua dilaksanakan tanggal 20 September 2018 dengan kegiatan unjuk kerja masing-masing keompok.

\section{Observasi Tindakan}

Selama pembelajaran berlangsung siswa nampak nampak menyiapkan diri pada penampilan mereka. Semua kelompok siap tampil, ada anggota kelompok yang satu angotanya tidak hadir sehingga menyebabkan mereka tampil kurang optimal. Namun demikian kelompok yang anggotanya tidak lengkap, dengan diberi motivasi untuk mengimprovisasi, mereka akhirnya memainkan perannya juga.

Dari data yang terkumpul di atas, dapat diketahui bahwa untuk kategori pertama yakni kategori pemahaman yang berupa pengungkapan kalimat yang saling terkait, siswa hanya mampu mengungkapkan 1 sampai 2 kalimat masih banyak siswa yang mengalami kesulitan. Aspek pelafalan merupakan aspek yang paling sulit bagi siswa. Masih banyak siswa melafalkan dialog dengan dialeg bahasa Ibu, dan beberapa orang siswa melafalkan ujaran yang kurang jelas sehingga mempengaruhi makna. Sementara untuk aspek isi cerita rata-rata siswa cukup baik. Aspek kelancaran dialog merupakan kategori yang paling sulit dialami siswa. Hal ini mengakibatkan banyak siswa yang tidak tuntas, dan hal ini membuat siswa kurang termotivasi dengan model pembelajaran ini. Hasil observasi dan perolehan data yang dapat dikumpulkan oleh peneliti dan pengamat sebagai berikut:

Diagram 1. Hasil Pembelajaran Berbicara Bahasa Indonesia Dengan Menggunakan Role Play Pada Siklus I

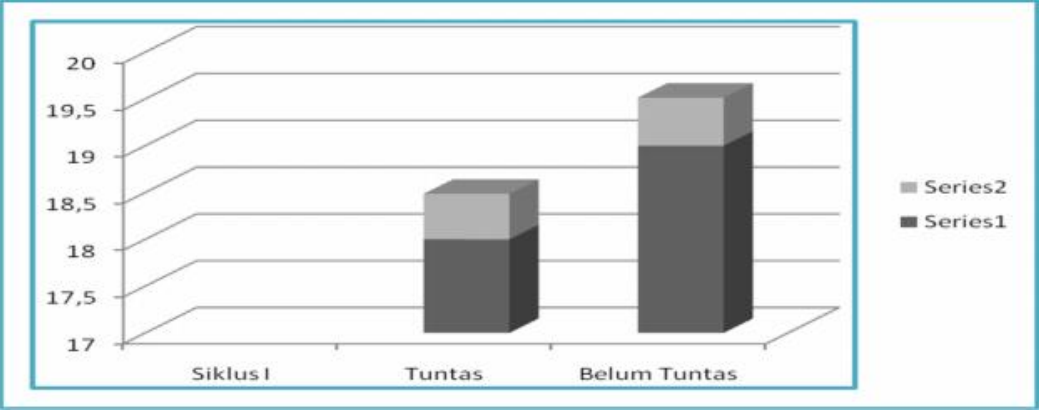

Data pada diagram 1 di atas menunjukkan bahwa secara keseleruhan terdapat 18 siswa atau $48.64 \%$ siswa dinyatakan mencapai ketuntasan belajar, sementara 19 siswa atau $51.35 \%$ siswa dinyatakan belum tuntas. Dari hasil tersebut penelitian dilanjutkan ke tindakan siklus II. 


\section{Refleksi Tindakan}

Untuk mendapatkan hasil yang optimal, banyak hal yang perlu diperbaiki pada tindakan siklus II, antara lain: 1) Setiap kelompok diberi kesempatan untuk mempelajari naskah secara baik, 2) Guru perlu memberi kesempatan siswa bertanya tentang hal-hal yang belum dipahami sebelum kegiatan role play, 3) Guru perlu mencontohkan cara meemrankan tokoh dengan benar sebagai patokan bagi siswa.

\section{Pembelajaran Siklus II}

\section{Penyusunan Rencana Tindakan}

Pada tahap ini, peneliti merancang penelitian dengan memoperhatikan hasil refeleksi tindakan siklus I. Lamanya penampilan ditingkatkan dari 8-10 menit menjadi 10-15 menit setiap kelompok.

Sehubungan dengan itu, maka dalam rancangan tindakan siklus II, dipuayakan agar guru mampu: (1) memberi motivasi, agar siswa dapat mencurahkan ide-idenya untuk dituangkan ke dalam dialog; (2) memfasilitasi setiap kelompok untuk mengoreksi kesalahan dalam penyusunan kalimat; (3) mengoreksi pelafalan dari kalimat yang baru mereka susun; (4) sebagai model dengan menunjukkan pada siswa bagaimana memerankan seorang tokoh; serta (5) menunjukkan strategi bagaimana tampil percaya diri, tidak malu-malu.

\section{Pelaksanaan Tindakan}

Seperti halnya pelaksanaan tindakan pada siklus pertama, setting tempat duduk diatur sesuai dengan ruang gerak role play. Waktu yang diperlukan untuk pelaksanaan tindakan pada siklus kedua ini 2 kali pertemuan, pertemuan pertama untuk memperbaiki narasi, dan semua kategori yang belum terpenuhi, sementara pertemuan kedua untuk pelaksanaan role play. Setiap kelompok siswa menampilkan masing-masing peran yang dibawakan dalam kelompok.

\section{Observasi Tindakan}

Hasil pengamatan selama proses pelaksanaan tindakan berlangsung pada siklus kedua ini, memang ada peningkatan walaupun belum semua siswa tampil sesuai dengan kriteria, terutama kategori isi cerita. Pada umumnya masing-masing kelompok sudah dapat menceritakan apa yang terjadi pada kehidupan di sekolah, isi cerita sudah baik. Kemampuan siswa dalam berekspresi sudah tepat sesuai dialog, keejlasan suara juga baik, gaya yang penuh penjiwaan serta tampil percaya diri. Data yang peneliti telah peroleh pada siklus kedua, terangkum pada diagram 4.2. sebagai berikut: 
Diagran 2. Hasil Pembelajaran Berbicara Bahasa Indonesia dengan Menggunakan Role Play Pada Siklus II

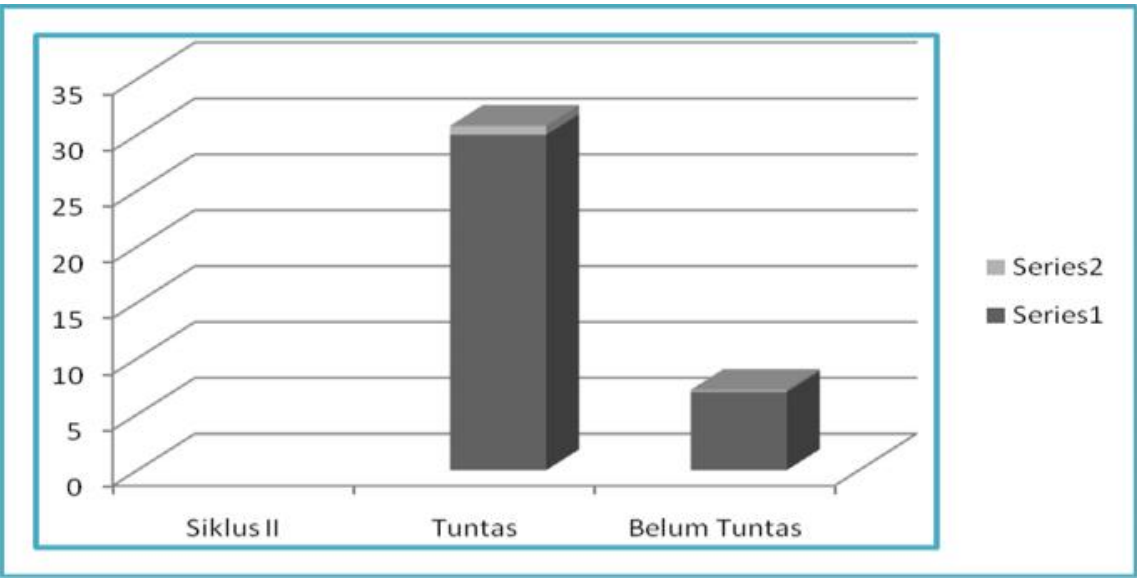

Dari enam aspek yang dinilai pada penggunaan role play siklus II berjalan dengan baik. Data pada diagram 4.2 di atas menunjukkan bahwa pelaksanaan tindakan siklus II yang melibatkan 5 kelompok belajar meningkatkan capaian belajar dibandingkan hasil siklus I. Secara keseluruhan terdapat 30 siswa atau 81.08\% dinyatakan mencapai ketuntasan belajar, sementara 7 siswa atau $18.91 \%$ siswa dinyatakan belum tuntas. Dengan demikian terjadi peningkatan dari tindakan siklus I ke siklus II adalah sebesar $31.44 \%$.

\section{Refleksi Tindakan}

Dari kendala yang terjadi pada siklus I dapat diatasi pada tindakan siklus II. Masing-masing anggota menunjukkan peningkatan yang signifikasi. Setiap kelompok mampu memerankan certia dengan lancar. Aspek kelancaran siswa nampak aktif dalam interaktif. Penelitipun menjadikan diri sebagai model untuk ditiru, misalnya dengan cara menirukan gaya dan suara seorang dokter yang sedang berkomunikasi dengan pasiennya. Bagi siswa yang tidak bertanya sama sekali, guru memancing pertanyaan agar siswa tersebut berani mengutarakan apa yang ada dalam pikirannya. Pemberian motivasi untuk tampil lebih baik, juga peneliti lakukan pada saat tanya jawab dalam kelompok.

\section{B. Pembahasan}

Penelitian tentang penggunaan role play sebagai model pembelajaran berhasil meningkatkan kemampuan berbicara pada siswa kelas IV SD Negeri 38 Kota Ternate. Pada awal penelitian di siklus pertama, siswa nampak kurang termotivasi untuk melakukan penelitian tindakan ini. Ada kesan bahwa siswa 
kurang berminat dengan kegiatan ini. Hal ini terlihat pada penampilan mereka yang terkesan asal - asalan, walaupun tidak semuanya. Secara umum capaian rata-rata pada tindakan siklus I adalah $48.64 \%$. Hal ini disebabkan guru belum maksimal dalam melakukan bimbingan baik secara individu maupun kelompok.

Adapun peningkatan dari tindakan siklus I ke siklus II adalah sebesar 31.44\%. Data menunjukkan bahwa hasil tindakan secara keseluruhan terdapat 30 siswa atau $81.08 \%$ dinyatakan mencapai ketuntasan belajar, sementara 7 siswa atau $18.91 \%$ siswa dinyatakan belum tuntas. Pembelajaran dengan menggunakan model role play ini akan bermanfaat bagi peningkatan kemampuan siswa dalam pemerolehan bahasa asing, karena pemahaman melalui pengalaman visual dapat tersimpan lama dalam benak siswa. Disamping itu ada kerja sama ataupun koordinasi yang terjalin baik antara guru dan siswa, tentunya hal ini dimaksudkan agar tujuan akhir pembelajaran bahasa Indonesia tercapai. Budden (2006: 74), role play adalah kegiatan berbicara dimana pemain dapat berperan menjadi orang lain atau dapat berperan menjadi dirinya sendiri tetapi berimajinasi dalam berbagai situasi. Hal ini sangat membantu siswa dalam mengembangkan kemampuan berimajinasi dan berbahasa lisan secara baik. Ladousse (1987:81) menegaskan role-play menambah variasi, perubahan perilaku dan kesempatan menggunakan kalimat dengan benar serta banyak kesenangan.

\section{SIMPULAN}

Dari hasil penelitian tindakan kelas tentang penggunaan role play dalam meningkatkan kemampuan berbicara siswa kelas IV SD Negeri 38 Kota Ternate dapat disimpulkan bahwa penggunaan model Role play mampu meningkatkan kualitas pembelajaran bahasa Indonesia.

Data siklus I menunjukkan terdapat 18 siswa atau $48.64 \%$ siswa dinyatakan tuntas belajar, sementara 19 siswa atau $51.35 \%$ siswa dinyatakan belum tuntas. Kemudian meningkat pada tindakan siklus II yaitu sebanyak 30 siswa atau $81.08 \%$ dinyatakan mencapai ketuntasan belajar, sementara 7 siswa atau $18.91 \%$ siswa dinyatakan belum tuntas. Adapun peningkatan dari tindakan siklus I ke siklus II adalah sebesar $31.44 \%$.

\section{DAFTAR PUSTAKA}

Akhadiah, dkk. 1988. Pembinaan Kemampuan Berbicara Bahasa Indonesia. Jakarta.Erlangga.

Arsjad. M.G. 1998. Pembinaan Kemampuan Berbicara. Bandung. Angkasa. 
Badan Standar Nasional Pendidikan. 2006. Panduan Penyusunan Kurikulum Tingkat Satuan Pendidikan Jenjang Pendidikan Dasar dan Menengah. Jakarta. BSNP

Ladousse, Gillian Porter. 1987. Role Play. Oxford: Oxford University Press.

Poole, Deborah and Thrush, Emily Austin. 1991. Interactions II: A Speaking Activities Book. Singapore: McGraw-hill, Inc.

Supriyadi. 2014. Pembelajaran Bahasa Indonesia Yang Menyenangkan. Bandung. UPI Press.

Tarigan, H.G. 1996. Berbicara Sebagai Suatu Keterampilan Berbahasa. Bandung. Angkasa.

Wiriatmaja. 2010. Metode Penelitian Tindakan Kelas. UNS Press. Surabaya. 